\title{
Homology of the $\mathrm{NH}_{2}$-Terminal Amino Acid Sequences of the Heavy and Light Chains of Human Monoclonal Lupus Autoantibodies Containing the Dominant 16/6 Idiotype
}

\author{
Peter M. Atkinson, Gary W. Lampman, Barbara C. Furie, Yaakov Naparstek, Robert S. Schwartz, \\ B. David Stollar, and Bruce Furie \\ Division of Hematology-Oncology, New England Medical Center, and the Department of Medicine, Department of Biochemistry and \\ Pharmacology, and Cancer Research Center, Tufts University School of Medicine, Boston, Massachusetts 02111
}

\begin{abstract}
The $\mathrm{NH}_{2}$-terminal amino acid sequences have been determined by automated Edman degradation for the heavy and light chains of five monoclonal IgM anti-DNA autoantibodies that were produced by human-human hybridomas derived from lymphocytes of two patients with systemic lupus erythematosus. Four of the antibodies were closely related to the idiotype system $16 / 6$, whereas the fifth antibody was unrelated idiotypically. The light chains of the $16 / 6$ idiotype-positive autoantibodies (HF2-1/13b, HF2-1/17, HF2-18/2, and HF3-16/6) had identical amino acid sequences from residues 1 to 40 . Their framework structures were characteristic of $V_{k} I$ light chains. The light chain of the 16/6 idiotype-negative autoantibody HF6-21/28 was characteristic of the $V_{\kappa} I I$ subgroup. The heavy chains of the $16 / 6$ idiotype-positive autoantibodies had nearly identical amino acid sequences from residues 1 to 40. The framework structures were characteristic of the $V_{H}$ III subgroup. In contrast, the GM4672 fusion partner of the hybridoma produced small quantities of an IgG with a $V_{H} I$ heavy chain and a $V_{\alpha} I$ light chain. The heavy chains of the lupus autoantibodies and the light chains of those autoantibodies that were idiotypically related to the $16 / 6$ system had marked sequence homology with WEA, a Waldenstrom IgM that binds to Klebsiella polysaccharides and expresses the $16 / 6$ idiotype. These results indicate a striking homology in the amino termini of the heavy and light chains of the lupus autoantibodies studied and suggest that the $V$ regions of the heavy and light chains of the 16/6 idiotype-positive DNA-binding lupus autoantibodies are each encoded by a single germ line gene.
\end{abstract}

\section{Introduction}

Systemic lupus erythematosus (SLE) ${ }^{1}$ is an autoimmune disease in which there are circulating autoantibodies that bind to

Dr. Atkinson is the recipient of a grant from the South African Medical Research Council. Dr. Naparstek is a fellow of the Fogarty International Center, South Africa.

Address reprint requests to Dr. Bruce Furie, New England Medical Center, 171 Harrison Ave., Boston, MA 02111.

Received for publication 12 June 1984 and in revised form 5 November 1984

1. Abbreviations used in this paper: $\mathrm{CDR}$, complementarity determining region; CDR1, CDR2, CDR3, complementarity determining regions 1, 2, and 3; ELISA, enzyme-linked immunosorbent assay(s); HFBA, heptafluorobutyric acid; PTH, phenylthiohydantoin; SLE, systemic lupus erythematosus; TBS, Tris-buffered saline.

J. Clin. Invest.

(c) The American Society for Clinical Investigation, Inc.

0021-9738/85/04/1138/06 \$1.00

Volume 75, April 1985, 1138-1143 nuclear, cytoplasmic, and other macromolecular antigens. The diversity of these serological reactions has confounded attempts to further our understanding of SLE. However, analyses of monoclonal autoantibodies produced by hybridomas from mice $(1-7)$ or humans $(8,9)$ with the disease have provided important immunochemical details of the autoantibody-antigen interaction. These monoclonal antibodies can react with a diverse group of molecules that includes nucleic acids, cardiolipin, the cytoskeletal protein vimentin, and with structures on the platelet surface (8-10). Such polyspecific autoantibodies seem to combine with structural elements, such as phosphodiester groups, that recur in a variety of molecules and on cell surfaces.

To evaluate further the monoclonal human lupus autoantibodies that we have analyzed immunochemically, we examined the primary structure of the amino terminus of the variable regions of the heavy and light chains of five antibodies. These antibodies (HF2-1/17, HF2-1/13b, HF3-16/6, HF2-18/2, and HF6-21/28), derived from the lymphocytes of two different patients in four separate fusions, bind to ssDNA and several synthetic polynucleotides and display minor reactivity to dsDNA (11). Four of the antibodies (HF2-1/17, HF21/13b, HF3-16/6, and HF2-18/2) also show platelet binding activity (8) and share the idiotype $16 / 6$ that occurs in high frequency in the serum of patients with active SLE (12).

\section{Methods}

The preparation of human-human hybridomas from lymphocytes of patients with SLE and the GM4672 cell line has been described previously (8). Antibodies produced by hybridoma cell lines HF2-1/17, HF2-1/13b, HF2-18/2, HF3-16/6, and HF6-21/28 were studied. Antibodies HF2-1/17, HF2-1/13b, HF2-18/2, and HF6-21/28 were derived from the same patient (the first three from blood lymphocytes and the fourth from splenic lymphocytes), whereas HF3$16 / 6$ was derived from a second patient.

Culture technique. Hybridoma cells were grown in vertical $175 \mathrm{~cm}^{2}$ flasks (Falcon Labware, Div. of Becton, Dickinson \& Co., Oxnard, CA) containing RPMI 1640 (Gibco Laboratories, Grand Islands, NY), $50 \mathrm{mM}$ Hepes, $20 \mathrm{mM}$ L-glutamine, $10 \%$ (vol/vol) fetal calf serum, 20 $\mathrm{mg} /$ liter gentamycin, $200 \mathrm{U} / \mathrm{ml}$ penicillin $\mathrm{G}$, and $20 \mathrm{mg} /$ liter streptomycin sulfate, $\mathrm{pH}$ 7.4. Tissue culture supernatant was harvested every $5 \mathrm{~d}$. A cell density of $2 \times 10^{6}$ cells $/ \mathrm{ml}$ was maintained.

Preparation of anti- $\mu$-agarose column. Serum $(100 \mathrm{ml})$ obtained from a rabbit immunized with human IgM was passed three times over an IgG-agarose column containing $100 \mathrm{mg}$ of human IgG (Sigma Chemical Co., St. Louis, MO) covalently coupled with Sepharose 4B $(5 \mathrm{mg} / \mathrm{ml}$ of gel; Pharmacia Fine Chemicals, Div. of Pharmacia, Inc., Piscataway, NJ). The material that failed to bind was then applied to an IgM-agarose column containing $70 \mathrm{mg}$ human IgM covalently coupled with Sepharose 4B $(5 \mathrm{mg} / \mathrm{ml})$. The $\mu$-chain-specific antibody (40 mg) was eluted with $0.1 \mathrm{M}$ glycine, $\mathrm{pH} 2.5$, and coupled with 15 $\mathrm{ml}$ of cyanogen bromide-activated Sepharose 4B.

Monoclonal antibody purification. Tissue culture supernatant (3 
liters) was precipitated with solid ammonium sulfate $(350 \mathrm{~g} / \mathrm{liter})$. After standing at $4^{\circ} \mathrm{C}$ overnight the precipitate was sedimented by centrifugation at $4,000 \mathrm{~g}$ for $1 \mathrm{~h}$. The resulting pellet was dissolved in a minimum volume of Tris-buffered saline (TBS) $(0.14 \mathrm{M} \mathrm{NaCl}, 0.5 \mathrm{M}$ Tris $\mathrm{HCl}, \mathrm{pH} \mathrm{7.4)}$ and dialyzed twice against 2 liters of TBS. Cell debris was removed by centrifugation for $10 \mathrm{~min}$. IgM was purified by immunoaffinity chromatography using the anti- $\mu$-agarose column. The antibody concentrate was applied to the anti- $\mu$-agarose column. After the column was washed with TBS, nonspecifically bound protein was removed with $1 \mathrm{M} \mathrm{NaCl}, 0.1 \%$ Tween 20 (Fisher Scientific Co., Allied Corp., Pittsburgh, PA) TBS. After further washing with TBS the antibody was eluted with $0.1 \mathrm{M}$ glycine $\mathrm{HCl}, \mathrm{pH} 2.5$, and neutralized with $1.0 \mathrm{M}$ Tris $\mathrm{HCl}, \mathrm{pH}$ 8.0. After concentration by ultrafiltration with a PM30 membrane (Amicon Corp., Scientific Sys. Div., Danvers, MA), $5 \mathrm{ml}$ of affinity-purified antibody $(2-4 \mathrm{mg} / \mathrm{ml})$ was applied in sucrose to a $1.0 \times 2.5-\mathrm{cm}$ Biogel A5m column (Bio-Rad Laboratories, Richmond, CA) equilibrated in TBS. The IgM-containing peak was pooled and concentrated by ultrafiltration. Sodium dodecyl sulfate (SDS) gel electrophoresis was performed using standard methods (13).

Reduction and carboxymethylation. The IgM solution was made 6 $\mathbf{M}$ in guanidine $\mathrm{HCl}$ (Schwarz/Mann, Becton Dickinson Immunodiagnostics, Orangeburg, NY), $5 \mathrm{mM}$ in EDTA, pH 8.2, and $0.1 \mathrm{M}$ in 2-mercaptoethanol (Bio-Rad Laboratories), and the protein was alkylated for $1 \mathrm{~h}$ at $37^{\circ}$ with iodoacetamide (Sigma Chemical Co.) at a final concentration of $0.12 \mathrm{M}$.

Separation of heavy and light chains. The lyophilized sample was dissolved in a minimal volume of $10 \%(\mathrm{vol} / \mathrm{vol})$ acetic acid and applied in sucrose to a column $(2.5 \times 100 \mathrm{~cm})$ of Sephadex G100 superfine (Pharmacia Fine Chemicals) equilibrated in 10\% (vol/vol) acetic acid (Pierce Chemical Co., Rockford, IL). The light chain was lyophilized, whereas the heavy chain was concentrated by ultrafiltration.

Protein sequencing. $1.0 \mathrm{mg}$ of light chain $(2 \mathrm{mg} / \mathrm{ml})$ dissolved in $10 \%(\mathrm{vol} / \mathrm{vol})$ acetic acid or $1.0 \mathrm{mg}$ of heavy chain $(2 \mathrm{mg} / \mathrm{ml})$ dissolved in heptafluorobutyric acid (HFBA) at $70^{\circ} \mathrm{C}$ for 2 min was applied to the spinning cup of a sequencer (model 890D; Beckman Instruments, Inc., Fullerton, CA) fitted with a cold trap. Polybrene and the 0.1-M Quadrol program were used routinely $(14,15)$. HFBA anhydride (1 $\mathrm{ml} / 50 \mathrm{ml}$ HFBA; Pierce Chemical Co.) and 2-mercaptoethanol $(20 \mu \mathrm{l} /$ $50 \mathrm{ml}$ ) (Bio-Rad Laboratories) were added to the HFBA. 2-Mercaptoethanol $(20 \mu \mathrm{l} / 50 \mathrm{ml})$ was also added to Quadrol.

Identification of phenylthiohydantoin (PTH) amino acids. After PTH amino acids were manually converted in $1 \mathrm{~N} \mathrm{HCl}$ and 2-mercaptoethanol ( $10 \mu \mathrm{l} /$ liter $)$, they were identified on a high-performance liquid chromatograph (Waters Associates, Millipore Corp. Milford, MA) fitted with a column (model C18 $\mu$-Bondapack; Waters Associates, Millipore Corp.), using an ammonium acetate-ethanol gradient (16) or on a Beckman high-performance liquid chromatograph (Beckman Instruments, Inc.) fitted with an ODS $15 \mathrm{~cm}$ column (Beckman Instruments, Inc.), using a lithium acetate-acetonitrile gradient (17).

Incorporation of ${ }^{3} \mathrm{H}$-amino acids into antibodies. Internal labeling of antibodies during synthesis with $\left[{ }^{3} \mathrm{H}\right]$ leucine and $\left[{ }^{3} \mathrm{H}\right]$ glycine was performed to identify the subgroup of IgG synthesized by the GM 4672 parent cell. A slight modification of the method of Galfre and Milstein was used (18). Briefly, $2 \times 10^{8}$ exponentially growing cells were washed three times in RPMI 1640 lacking either leucine or glycine (Gibco Laboratories). One-tenth of $1 \mathrm{ml}$ of the ${ }^{3} \mathrm{H}$-amino acid $(1 \mathrm{mCi} / \mathrm{ml})$ (New England Nuclear, Boston, MA) was added to $10 \mathrm{ml}$ of the amino-acid-deficient medium and incubated for $20 \mathrm{~h}$. Thereafter, $10 \mathrm{ml}$ of complete medium with $15 \%$ fetal calf serum was added and the incubation continued for an additional $6 \mathrm{~h}$. Thereafter, $20 \mathrm{mg}$ of unlabeled antibody was added as a carrier. In the case of the hybridomas, purified monoclonal antibody was used, whereas polyclonal IgG (Sigma Chemical Co.) was added to the GM 4672 supernatant. After automated Edman degradation, each residue was assayed for ${ }^{3} \mathrm{H}$ activity in a $\beta$-scintillation spectrometer (model LS 1800; Beckman Instruments, Inc.).

Enzyme-linked immunosorbent assays (ELISA) for IgM and IgG. Microtiter plates were coated with either anti- $\mu$-chain or anti- $\gamma$-chain antibody $(5 \mu \mathrm{g} / \mathrm{ml}$ in $0.05 \mathrm{M}$ borate, $\mathrm{pH} 8.6)$ for $16 \mathrm{~h}$ at $4^{\circ} \mathrm{C}$. After three washes with TBS, $0.01 \mathrm{ml}$ of hybridoma antibody diluted in $1 \%$ bovine serum albumin was added. After $1 \mathrm{~h}$ incubation at $37^{\circ}$, plates were washed three times with TBS $/ 0.1 \%$ Tween 20 . Thereafter $0.1 \mathrm{ml}$ of alkaline-phosphatase-conjugated anti- $\mu$ - or anti- $\gamma$-chain specific antisera (Sigma Chemical Co.) was added and the plates incubated for $1 \mathrm{~h}$ at $37^{\circ} \mathrm{C}$. After washing three times with TBS, $0.1 \mathrm{ml}$ of p-nitrophenylphosphate $\left(1.0 \mathrm{mg} / \mathrm{ml}\right.$ in $0.05 \mathrm{M} \mathrm{Na}_{2} \mathrm{CO}_{3}, \mathrm{pH} 9.5$, and $2 \mathrm{mM} \mathrm{MgCl}_{2}$ ) was added. After incubation at $37^{\circ} \mathrm{C}$ for $15-30 \mathrm{~min}$, the absorbance at $405 \mathrm{nM}$ was recorded on a microELISA reader (model 52; Dynatech Laboratories, Inc., Dynatech Corp., Alexandria, VA).

Competition ELISA for 16/6 idiotype. Preparation of a rabbit antiidiotypic serum (anti-16/6) and competitive immunoassays of monoclonal antibodies for the $16 / 6$ idiotype were carried out as previously described (19). In brief, each IgM was tested at a variety of concentrations for its ability to inhibit the binding of rabbit anti-16/6 antibody to IgM HF3-16/6 bound to a solid phase. Bound rabbit immunoglobulin was detected using the ELISA method with goat antirabbit antibody.

\section{Results}

Cell lines. The hybridoma clones HF2-1/17, HF2-18/2, HF2$1 / 13 \mathrm{~b}, \mathrm{HF} 3-16 / 6$, and HF6-21/28 were maintained in continuous culture. At the time of harvest, the tissue culture supernatant contained $5-10 \mu \mathrm{g} / \mathrm{ml}$ of $\mathrm{IgM}$ and $10-20 \mathrm{ng} / \mathrm{ml}$ of $\mathrm{IgG}$, as determined with a solid phase ELISA.

Antibody purification. In a typical preparation starting with 3 liters of tissue culture supernatant, $\sim 20 \mathrm{mg}$ of antibody was obtained. This IgM preparation migrated as a single band upon SDS gel electrophoresis. Using anti- $\mu$ and anti- $\gamma$ antisera, the antibody was confirmed as an IgM.

Separation of light and heavy chains. The purified IgM was reduced and carboxymethylated, and the heavy and light chains were separated by gel filtration. These isolated chains migrated as single bands upon SDS gel electrophoresis.

Amino acid sequence of light chains. The light chains of the IgM from clones HF2-1/13, HF2-1/17, HF2-18/2, HF3$16 / 6$, and HF6-21/28 were subjected to automated Edman degradation. The light chains were degraded through residue 40 with a repetitive yield of $95-96 \%$ and a recovery of 60 $70 \%$. With the exception of IgM HF2-18/2, PTH amino acids were unambiguously identified through residue 40 ; IgM HF2$18 / 2$ yielded sequence data through residue 37 . As shown in Fig. 1, the amino terminal residues of the light chains of HF3$16 / 6$, HF2-1/13b, HF2-1/17, and HF2-18/2 were identical. Their framework sequences are characteristic of the $V_{k} I$ subgroup. The sequence of the light chain of HF6-21/28 indicated a framework structure characteristic of the $\mathrm{V}_{\alpha} \mathrm{II}$ subgroup.

Amino acid sequence of heavy chains. The heavy chains were insoluble in acetic acid and in water but were soluble in HFBA at $70^{\circ} \mathrm{C}$. The reduced and carboxymethylated heavy chains from IgM derived from clones of HF2-1/13b, HF2$1 / 17$, HF2-18/2, and HF3-16/6 were subjected to automated Edman degradation, and residues 1-40 were identified. The amino terminal 40 residues of these heavy chains displayed marked sequence homology (Fig. 2). The framework sequences were characteristic of the $\mathrm{V}_{\mathrm{H}} \mathrm{III}$ subgroup.

Comparison of the IgM produced by human hybridomas and the IgG produced by the parental GM4672 cell line. The marked similarity of the heavy and light chains of the IgM autoantibodies raised the question of the relationship of their 

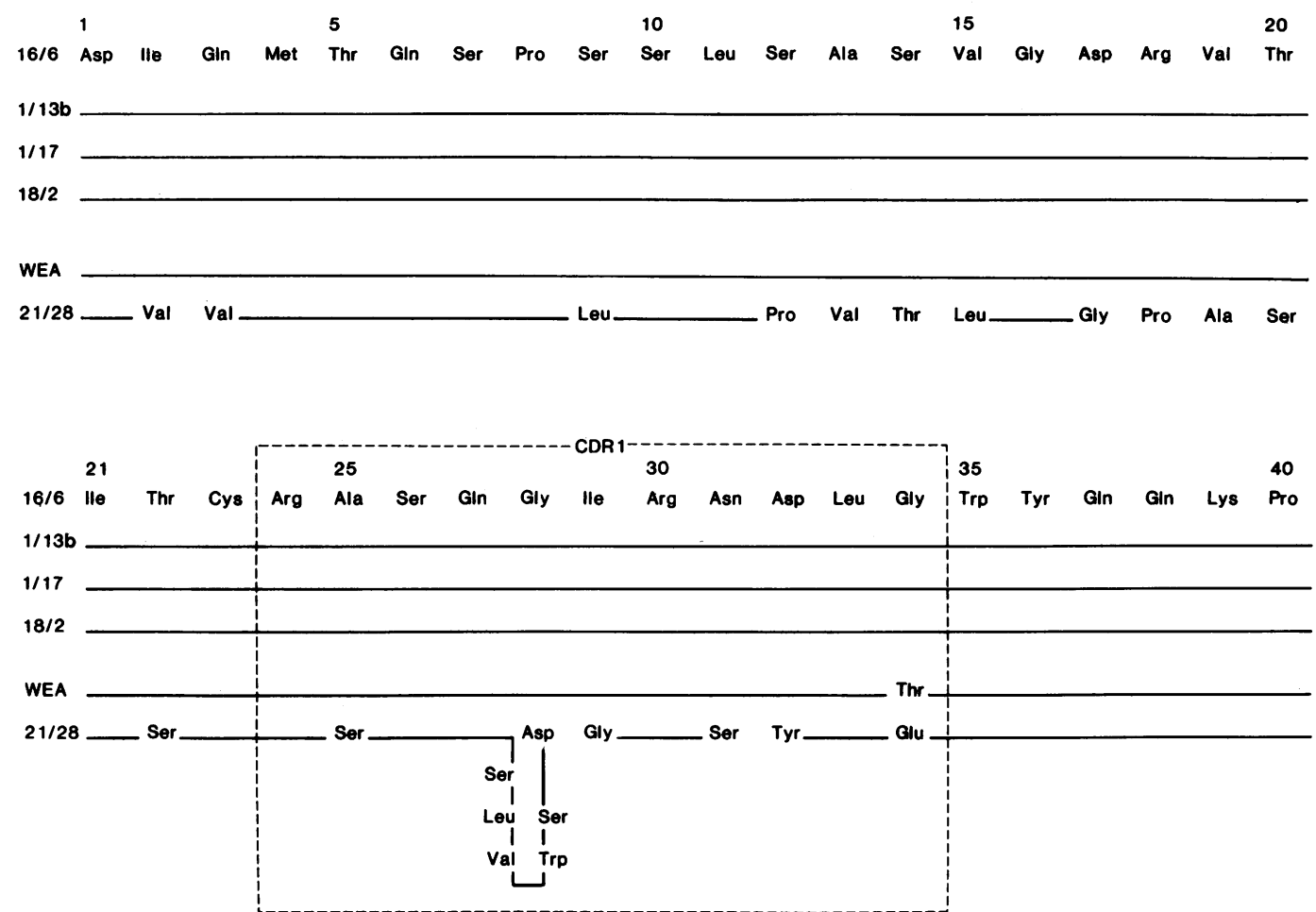

Figure 1. Comparison of the $\mathrm{NH}_{2}$-terminal amino acid sequences of the light chains of human monoclonal IgM lupus autoantibodies.

The light chain sequence of HF3-16/6, from residues 1 to 40 , is compared with those of IgM HF2-1/13b, HF2-1/17, HF2-18/2, HF6$21 / 28$, and the WEA protein.

izes each of the heavy chain and light chain subgroups (18), the subgroup of the heavy and light chains could be identified. Culture supernatant containing ${ }^{3} \mathrm{H}$-immunoglobulins was mixed with hybridoma supernatants grown without radioactive supplements. The immunoglobulins were purified and the heavy and light chains were separated and subjected to automated Edman degradation. The first 40 residues of the GM4672 heavy chain demonstrated $\left[{ }^{3} \mathrm{H}\right]$ leucine only at residue 4 . In

GM4672 cell line in media containing radioactive leucine Since the sequence pattern of leucine incorporation character-

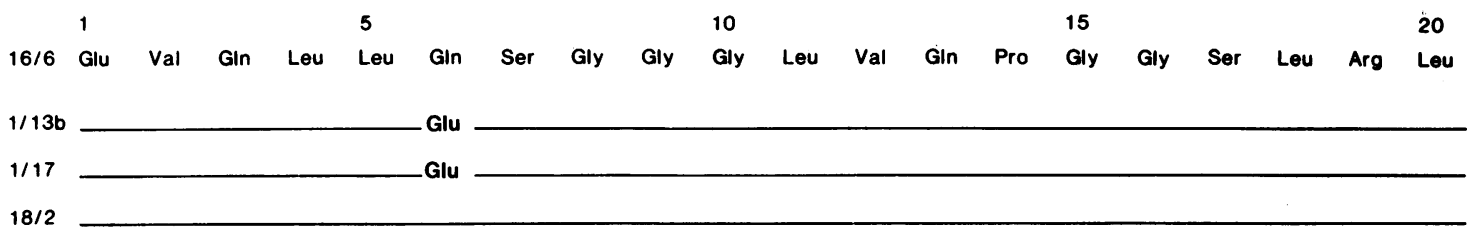

WEA PCA Val Asp Glu

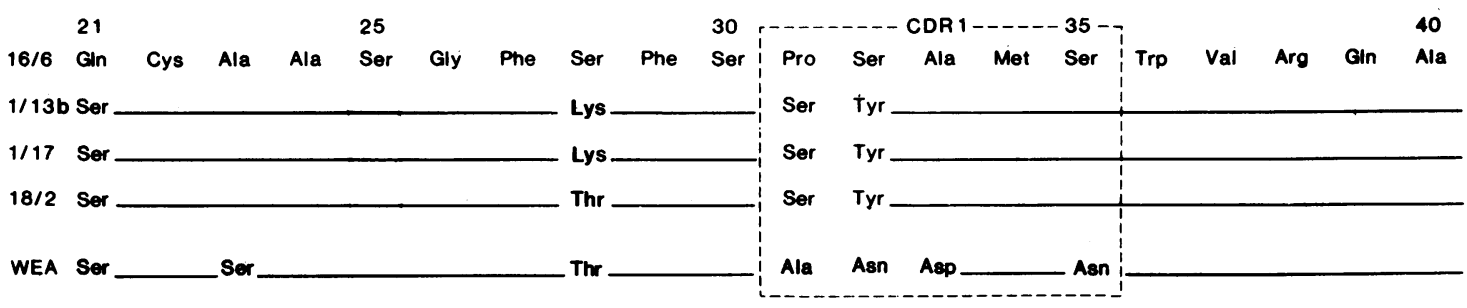

Figure 2. Comparison of the $\mathrm{NH}_{2}$-terminal amino acid sequences of the heavy chains of the human monoclonal IgM lupus autoantibodies. The IgM immunoglobulins studied are defined in Fig. 1. 
contrast, the IgM autoantibody heavy chains contained leucine at residues $4,5,11,18$, and 20 . These results suggest that the heavy chain of the secretory product of the GM4672 line is of the $V_{H} I$ subgroup. The light chain of the IgG secreted by the GM4672 cell line incorporated $\left[{ }^{3} \mathrm{H}\right]$ leucine at residues 11 and 33 , indicative of a $\mathrm{V}_{\kappa} \mathrm{I}$ subgroup. Incorporation of $\left[{ }^{3} \mathrm{H}\right]$ glycine into the parental IgG and subsequent Edman degradation of the light chain disclosed $\left[{ }^{3} \mathrm{H}\right]$ glycine at residue 16 , but there was no incorporation into residues 28 and 34 . The IgM autoantibody light chains, by contrast, contained glycine at residues 28 and 34 . These results indicate that the structures of the variable regions of each IgM studied differ from the variable regions of the immunoglobulin produced by the GM4672 cell line.

Expression of the dominant 16/6 idiotype. The lupus IgM autoantibodies were evaluated for the expression of the highfrequency 16/6 idiotype (12). As shown in Fig. 3, HF3-16/6, HF2-1/17, HF2-1/13b, and HF2-18/2 contain this idiotype. In contrast, HF6-21/28, with a structurally different light chain, lacks this idiotype. WEA, a Waldenstrom macroglobulin that binds to pyruvylated galactose of the capsular polysaccharide of Klebsiella pneumoniae, has marked sequence homology with the lupus autoantibodies studied, with the exception of HF6-21/28 (20). As shown in Fig. 3, the WEA IgM was also a member of the $16 / 6$ idiotypic system. These results suggest that the $16 / 6$ idiotype may be associated with the light chain, since the IgMs that expressed this idiotype have ideritical or nearly identical amino-terminal sequences.

\section{Discussion}

The $\mathrm{NH}_{2}$-terminal amino acid sequences of the light and heavy chains of five human monoclonal IgM lupus autoantibodies have been determined. Analysis of the light chains for four immunoglobulins that express the $16 / 6$ idiotype revealed

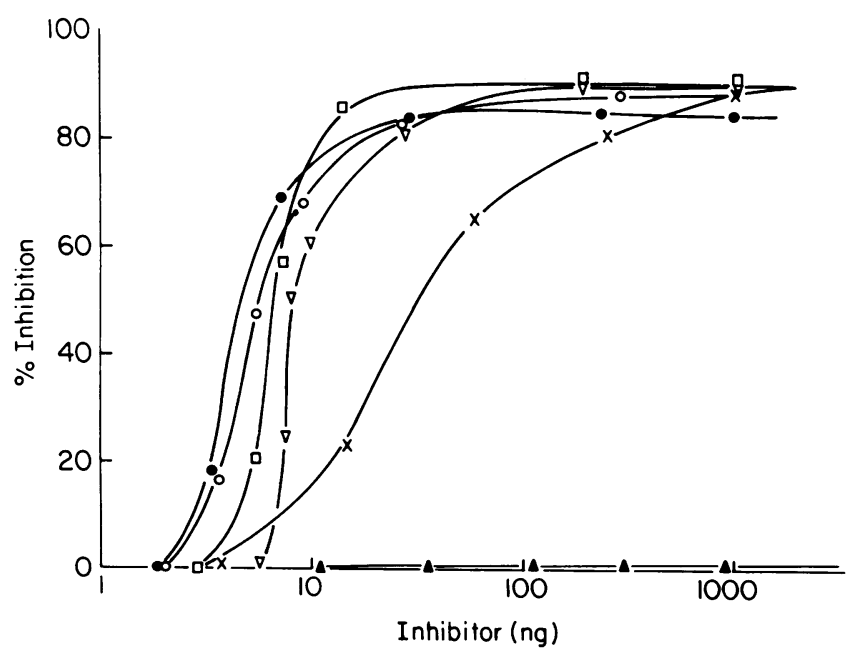

Figure 3. Expression of the $16 / 6$ idiotype by monoclonal autoantibodies and the WEA Waldenstrom macroglobulin. The 16/6 idiotype was measured by the ability of each IgM to inhibit the binding of rabbit anti-16/6 antibody to HF3-16/6 bound to the solid phase. In experiments involving WEA, theWEA protein was on the solid phase. $\square$, HF2-1/17; $\nabla$, HF2-18/2; O, HF2-1/13b; •, HF3-16/6; $\triangle$, HF6-21/28; $\times$, WEA. identical primary structures within the first 40 residues. The framework regions were characteristic of the $V_{k} I$ subgroup. With the exception of threonine 22 , the amino acids in the framework structure within the first 40 amino acids were those observed with the highest frequency in other $V_{\alpha} I$ subgroups (21). For the structures analyzed, the autoantibodies exhibited within the framework residues a homology of $98 \%$. The complementarity determining region 1 (CDR1) contained a glycine 28 , arginine 30 , asparagine 31 , aspartic acid 32 , and glycine 34 that were not observed in the $V_{\kappa} I$ subgroups with highest frequency. The sequence available indicates a striking similarity to the light chain of WEA (20), a Waldenstrom IgM that binds to 3,4 pyruvylated galactose in the Klebsiella polysaccharide $\mathrm{K} 30$ (22). Complete identity of the $\mathrm{NH}_{2}$-terminal sequences of the four 16/6 idiotype-positive IgM autoantibody light chains and the WEA IgM light chain can be noted, with the single exception of threonine 34 being substituted for glycine 34 in the WEA protein. The HF6-21/28 anti-DNA autoantibody was 16/6 idiotype-negative; its light chain was distinct from the other autoantibody light chains studied and it belongs to a different $\mathrm{V}_{\mathrm{L}}$ subgroup, $\mathrm{V}_{\kappa} \mathrm{II}$.

The heavy chains of the autoantibodies also showed homology. The framework regions of all five anti-DNA antibodies were characteristic of the $\mathrm{V}_{\mathrm{H}}$ III subgroup. With the exception of residues 5 and 6 , each amino acid observed was seen with highest frequency in this subgroup. The framework residues within the first 40 amino acids of the four heavy chains analyzed showed identity in 32 of 35 residues $(91 \%)$. IgM HF2-1/13b, HF2-1/17, and HF2-18/2 were derived from the same patient by two separate fusions and were identical in 33 of 35 residues $(94 \%)$. Residues 31 and 32 in the CDR1 were Pro-Ser in HF3-16/6 and Ser-Tyr in HF2-1/13b, HF2-1/17, and HF2-18/2. The heavy chain of IgM HF6-21/28, which was $16 / 6$ idiotype-negative, was incompletely analyzed. Despite their marked homology, the $\mathrm{NH}_{2}$-terminal sequences of $\mathrm{HF} 3$ $16 / 6$, HF2-1/17, and HF2-18/2 were not identical, whereas HF2-1/17 and HF2-1/13b (derived from the same fusion) shared equivalent structures.

The homology of the $\mathrm{NH}_{2}$-terminal 40 residues of the WEA heavy chain and of the heavy chains of the lupus autoantibodies was less striking. The CDR1 showed no homology except with the invariant methionine 34 . The framework regions were characteristic of the $\mathrm{V}_{\mathrm{H}}$ III subgroup, but only 30 of 35 residues $(85 \%)$ were shared.

All five of these autoantibodies bind to DNA, but the details of their immunochemical reactions differ (11). HF2$18 / 2$, for example, reacts strongly with the synthetic polyneucleotide poly(dT), whereas HF2-1/13b does not react with poly(dT). Yet both antibodies had identical sequences in the CDR1 of their heavy and light chains. These results suggest that the CDR2 and CDR3 of these immunoglobulins may not be equivalent.

The 16/6 idiotype was expressed on HF3-16/6, HF2-18/2, HF2-1/17, HF2-1/13b, as well as on the WEA protein. The structural correlate of this idiotype on the IgM autoantibodies remains uncertain since only a portion of the variable region has been sequenced. The CDR 1 of the heavy chain, or parts of the heavy chain framework regions, seem unlikely candidates because the heavy chain of WEA (idiotype-positive) showed only modest sequence homology with the heavy chains of lupus autoantibodies. The 16/6 idiotype may therefore reside 
in the variable regions of the light chains, but the complete sequences of the variable regions of these and other autoantibodies heed to be determined to fully answer this question.

Structural studies of murine monoclonal anti-arsonate antibodies bearing the predominant idiotype of that system, $I^{C R}$, have revealed that it comprises a family of related $V$ regions that arose by somatic diversification of germ line $V_{H}$ and $V_{L}$ genes $(23,24)$. Similar results have been obtained with T15 idiotype-positive anti-phosphocholine antibodies and in the (4-hydroxy-3-nitrophenyl)acetyl hapten system (reviewed by Rajewsky and Takemori [25]). The structural similarity of the $\mathrm{NH}_{2}$-terminal amino acid sequences of the $16 / 6$ positive monoclonal lupus autoantibodies and the WEA macroglobulin suggests that the antibodies also stem from common germ line $V_{H}$ and $V_{L}$ genes. Since these autoantibodies were derived from unrelated patients, the postulated $\mathrm{V}$ genes are probably broadly distributed in humans.

The conservation of such $\mathrm{V}$ genes in the germ line implies that the original specificity of the corresponding antibody is not directed at DNA but at some environmental antigen. Perhaps it is no coincidence that the WEA protein, which is structurally similar to four anti-DNA autoantibodies, binds to a capsular polysaccharide of Klebsiella pneumoniae (22). Analogous findings have recently been reported with monoclonal mouse antibodies. Eilat et al. (26) found marked homology of the amino acid sequence of the heavy chain of an NZB/NZWderived monoclonal antibody against double-stranded DNA with that of an anti-phosphorylcholine antibody from a CBA/ $\mathrm{J}$ mouse. Phosphorylcholine is an important microbial antigen, and anti-phosphorylcholine antibodies protect mice against lethal infection with rough pneumococci and other bacteria (27). A somatic mutant of a monoclonal anti-phosphorylcholine antibody has been studied by Diamond and Scharff (28). The mutant immunoglobulin differs from the original antibody by a single amino acid substitution in the first heavy chain hypervariable region and fails to bind to phosphorylcholine, but it does bind to double-stranded DNA and cardiolipin in a manner similar to that of a typical polyspecific lupus autoantibody. These structural analyses of mouse antibodies, together with the results of our studies with human monoclonal autoantibodies, suggest that anti-DNA antibodies are related to anti-bacterial antibodies. The autoantibodies may arise by mutation of $\mathrm{V}$ genes that encode anti-bacterial antibodies, as the work of Diamond and Scharff (28) indicates, or they may be the products of germ line $\mathrm{V}$ genes that react with epitopes in both bacterial and polynucleotide antigens, as indicated by immunochemical analyses of monoclonal anti-DNA and antibacterial antibodies (Neparstek, Y., D. Duggan, A. Schattner, M. Madaio, E. Kabat, B. D. Stollar, and R. S. Schwartz, manuscript submitted for publication). These two mechanisms are not mutually exclusive, and both may participate in the generation of anti-DNA antibodies.

\section{Acknowledgments}

We thank Dr. Yehuda Shoenfeld for many helpful discussions in the early phases of this work.

This work was supported by grants HL30921, AI19794, and AM27232 from the National Institutes of Health and by a grant from Seragen, Inc.

\section{References}

1. Andrzejewski, C., Jr., B. D. Stollar, T. M. Lalor, and R. S. Schwartz. 1980. Hybridoma autoantibodies to DNA. J. Immunol. 124: 1499-1502.

2. Eilat, D., R. Asofsky, and R. Laskov. 1980. A hybridoma from an autoimmune NZB/NZW mouse producing monoclonal antibody to ribosomal-RNA. J. Immunol. 124:766-768.

3. Andrzejewski, C., Jr., J. Rauch, E. Lafer, B. D. Stollar, and R. S. Schwartz. 1981. Antigen-binding diversity and idiotypic crossreactions among hybridoma autoantibodies to DNA. J. Immunol. 126 : 226-231.

4. Pages, J. M., and A. E. Bussard. 1978. Establishment and characterization of a permanent murine hybridoma secreting monoclonal autoantibody. Cell. Immunol. 41:188-194.

5. Klotz, J. L., M. L. Phillips, M. M. Miller, and R. L. Teplitz. 1981. Monoclonal autoantibody production by hybrid cell lines. Clin. Immunol. Immunopathol. 18:368-374.

6. DeHeer, D. H., J. M. Pages, and A. E. Bussard. 1980. Specificity of antierythrocyte autoantibodies secreted by a NZB-derived hybridoma and NZB peritoneal cells. Cell. Immunol. 49:135-141.

7. Tron, F., D. Charron, J.-F. Bach, and N. Talal. 1980. Establishment and characterization of a murine hybridoma secreting monoclonal anti-DNA autoantibody. J. Immunol. 125:2805-2809.

8. Shoenfeld, Y., S. C. Hsu-Lin, J. E. Gabriels, L. E. Silberstein, B. C. Furie, B. Furie, B. D. Stollar, and R. S. Schwartz. 1982 Production of autoantibodies by human-human hybridomas. J. Clin. Invest. 170:205-208.

9. Andre-Schwartz, J., S. K. Datta, Y. Shoenfeld, D. A. Isenberg, B. D. Stollar, and R. S. Schwartz. 1984. Binding of cytoskeletal proteins by monoclonal anti-DNA lupus autoantibodies. Clin. Immunol. Immunopathol. 31:261-271.

10. Lafer, E. M., J. Rauch, C. Andrzejewski, Jr., D. Mudd, B. C. Furie, B. Furie, R. S. Schwartz, and B. D. Stollar. 1981. Polyspecific monoclonal lupus autoantibodies reactive with both polynucleotides and phospholipids. J. Exp. Med. 153:897-909.

11. Shoenfeld, Y., J. Rauch, H. Massicotte, S. Datta, J. AndreSchwartz, B. D. Stollar, and R. S. Schwartz. 1983. Polyspecificity of monoclonal lupus autoantibodies produced by human-human hybridomas. N. Engl. J. Med. 308:414-420.

12. Isenberg, D. A., Y. Shoenfeld, M. P. Madaio, J. Rauch, M. Reichlin, B. D. Stollar, and R. S. Schwartz. 1984. Anti-DNA antibody idiotypes in systemic lupus erythematosus. Lancet. II:417-421.

13. Laemmli, U. K. 1970. Cleavage of structural proteins during the assembly of the head of bacteriophage T4. Nature (Lond.). 227: 680-685.

14. Klapper, D. G., C. E. Wilde III, and J. D. Capra. 1978. Automated amino acid sequencing of small peptides utilizing polybrene. Anal. Biochem. 85:126-131.

15. Brauer, A. W., M. N. Margolies, and E. Haber. 1975. The application of $0.1 \mathrm{M}$ Quadrol to the microsequence of proteins and the sequence of tryptic peptides. Biochemistry. 14:3029-3035.

16. Fohlman, J., L. Rask, and P. A. Peterson. 1980. High-pressure liquid chromatographic identification of phenylthiohydantoin derivatives of all twenty common amino acids. Anal. Biochem. 106:22-26.

17. Moser, P. W., and E. E. Rickli. 1979. Identification of amino acid phenylthiohydantoins by gradient high performance liquid chromatography on Spherisorb S-5-ODS. J. Chromatogr. 176:451-455.

18. Galfre, G., and C. Milstein. 1982. Chemical typing of human kappa light chain subgroups expressed by human hybrid myelomas. Immunology 45:125-128.

19. Shoenfeld, Y., D. A. Isenberg, J. Rauch, M. P. Madaio, B. D Stollar, and R. S. Schwartz. 1983. Idiotypic cross-reactions of monoclonal human lupus autoantibodies. J. Exp. Med. 158:718-730.

20. Goni, F., and B. Frangione. 1983. Amino acid sequence of the 
Fv region of a human monoclonal IgM (protein WEA) with antibody activity against 3,4-pyruvylated galactose in Klebsiella polysaccharides K30 and K33. Proc. Natl. Acad. Sci. USA. 80:4837-4841.

21. Kabat, E. A., T. T. Wu, H. Bilofsky, M. Reid-Miller, and H. Perry. 1983. Sequences of Proteins of Immunological Interest. National Institutes of Health, Bethesda, MD.

22. Kabat, E. A., G. Liao, H. Bretting, E. C. Franklin, D. Geltner, B. Frangione, M. E. Koshland, J. Shyong, and E. F. Osserman. 1980. Human monoclonal macroglobulins with specificity for Klebsiella $\mathrm{K}$ polysaccharides that contain 3,4-pyruvylated-D-galactose and 4,6-pyruvylated-D-galactose. J. Exp. Med. 152:979-995.

23. Marshak-Rothstein, A., M. Siekevitz, M. N. Margolies, M. Mudgett-Hunter, and M. L. Gefter. 1980. Hybridoma proteins expressing the predominant idiotype of the anti-azophenylarsonate response of A/J mice. Proc. Natl. Acad. Sci. USA. 77:1120-1124.

24. Siekevitz, M., S. Y. Huang, and M. L. Gefter. 1983. The genetic basis of antibody production: a single heavy chain variable region gene encodes all molecules bearing the dominant anti-arsonate idiotype in the strain A mouse. Eur. J. Immunol. 13:123-132.

25. Rajewsky, K., and T. Takemori. 1983. Genetics, expression and function of idiotypes. Annu. Rev. Immunol. 1:569-608.

26. Eilat, D., M. Hochberg, J. Pomphrey, and S. Rudikoff. 1984. Monoclonal antibodies to DNA and RNA from NZB/NZW $F_{1}$ mice: antigenic specificities and $\mathrm{NH}_{2}$ terminal amino acid sequences. $J$. Immunol. 133:489-494.

27. Briles, D. E., C. Forman, S. Hudak, and J. L. Claflin. 1982. Anti-phosphorylcholine antibodies of the T15 idiotype are optimally protective against Streptococcus pneumoniae. J. Exp Med. 156:11771185.

28. Diamond, B., and M. Scharff. 1984. Somatic mutation of the T15 heavy chain gives rise to an antibody with autoantibody specificity. Proc. Natl. Acad. Sci. USA. 81:5841-5844. 